\title{
Természetes és mesterséges nanopórusok számítógépes szimulációja
}

\author{
BODA Dezső, VALISKÓ Mónika, FERTIG Dávid, MÁDAI Eszter, \\ SARKADI Zsófia, HATÓ Zoltán és KRISTÓF Tamás
}

Természettudományi Központ, Mérnöki Kar, Pannon Egyetem, Egyetem utca 10., 8200 Veszprém, Magyarország

\section{Bevezetés}

Korunk jelentős müszaki fejlődése indokolja újabb és újabb, egyre fejlettebb anyagi rendszerek kialakítását. A miniatürizáció olyan eszközök fejlesztését teszi szükségessé, amelyekben az eszköz lényegi feladatát ellátó „központi egység" mérete a nanotartományba esik, és az ezekben lejátszódó folyamatok molekuláris szintű megértése szükséges az eszközök müködésének megértéséhez és új eszközök tervezéséhez.

A Pannon Egyetem Komplex Molekuláris Rendszerek kutatócsoportja** által tanulmányozott anyagi rendszerek közös nevezője, hogy nanométeres tartományba tartozó pórusokat tartalmaznak. Ezekben a pórusokban adszorpció, interkaláció, vagy anyagtranszport játszódik le, amely folyamatok az eszközök bemeneti és kimeneti jelei között olyan speciális kapcsolatot tesznek lehetővé, amik aztán az eszköz müködésének alapját képezik.

A kutatócsoportban tanulmányozott rendszerek egyik nagy csoportját a pórusos aluminoszilikátok, ezen belül egyes nanopórusos zeolitok és agyagásványok képezik. A nanopórusos zeolitok molekuláris méretű kalitkákat és csatornákat tartalmazó, nagyon szabályos felépítésű kristályos anyagok, és ezeknél molekuláris szimulációkkal jól vizsgálható az a kérdés, hogy a pórusméreten túl az atomi szintü szerkezet finom részletei hogyan befolyásolják kismolekulák adszorpcióját, vagy éppen korlátoktól mentes áthaladását. Ebben a tanulmányban a másik vizsgált anyagfajtának, az agyagásványoknak egy jellegzetes képviselőjére, a kaolinitra vonatkozó eredményeink egymásra épülő részeibe engedünk betekintést.

Egy másik nagy csoportba olyan rendszerek tartoznak, ahol a pórusok egy membránon keresztül két tömbfázisú elektrolit között szabályozott iontranszportot tesznek lehetővé. Kutatásaink természetes és mesterséges nanopórusok modellezéses vizsgálataira vonatkoznak. A természetes nanopórusok pl. az ioncsatornák ${ }^{1}$; a kutatócsoport nátriumés kalciumcsatornákra rendelkezik szerteágazó eredményekkel. ${ }^{2-7}$ A nanotechnológiai úton előállított mesterséges nanopórusok sokféle feladatra használhatók, amik közül az általunk is tanulmányozott szenzormüködést említhet- jük..$^{8-11}$ Ebben a tanulmányban a nanopórusok egy fundamentális tulajdonságát, a skálázhatóságot mutatjuk be. ${ }^{12-16}$

Ezen jelenségek molekuláris szintű megértéséhez napjainkra az anyagvizsgálati módszerek kanonizált elemévé vált modellezéses eljárások szükségesek, mivel a kísérleti módszerek a molekuláris skálán csak korlátozottan használhatók. Mi a modelljeinkhez alapvetően definiáljuk a rendszert alkotó részecskék között ható kölcsönhatásokat, majd a gondosan felépített modellt egy a statisztikus mechanikán alapuló számítógépes szimulációs módszerrel vizsgáljuk. Ezek a módszerek úgy müködnek, mint egy virtuális mikroszkóp, amivel betekintést nyerünk a dolgok molekuláris szintü müködésébe. Két alapvető klasszikus szimulációs technika létezik: a Newton-féle mozgásegyenletek megoldásán alapuló molekuláris dinamikai (MD) és az állapotok valószínűségi eloszlásán alapuló Monte Carlo (MC) módszer. ${ }^{17-18}$ Ebben a cikkben mindkettőre mutatunk példát.

\section{Kaolinit interkalációjának és exfoliációjának szimulációja}

A kaolinit a rétegszilikátok alosztályába tartozó, ún. 1:1-típusú agyagásvány. Szerkezete réteges, szendvicsszerűen épül fel. A kaolinit semleges töltésü, de enyhe polárossággal bíró bázislapja kétféle sík egymásra rétegeződésével jön létre. $\mathrm{Az}$ egyik sík $\mathrm{SiO}_{4}$ tetraéderes elemekből felépülő réteg, szabályos hatszöges elrendeződéssel, amely egy oxigén atomon keresztül egy oktaéderes (dioktaéderes) szerkezetü $\mathrm{AlO}_{2}(\mathrm{OH})_{4}$ réteghez kötődik (a kaolinit összegképlete: $\left.\mathrm{Al}_{2} \mathrm{Si}_{2} \mathrm{O}_{5}(\mathrm{OH})_{4}\right)$. A kaolinitlapokat hidrogénhíd-kötések tartják össze. Ezek felszakításával a lapok közötti térbe néhány kisebb molekula könnyen be tud épülni, a lapok távolsága ilyenkor megnövekszik, és jól meghatározott bázislaptávolsággal rendelkező stabil komplexek jönnek létre. A vendégmolekuláknak ilyen beépülését interkalációnak nevezzük. A kisebb molekulákat különböző eljárásokkal gyakran lecserélik egyre nagyobb helyigényüekre, olyanokra is, amelyek spontán módon (egy lépcsőben) nem lennének képesek interkalálódni. Így egyre nagyobb bázislaptávolsággal jellemzett kaolinitkomplexek jönnek létre. Egyes esetekben a kaolinitlapok annyira eltávolodnak egymástól, hogy a struktúra stabilitása megszünik, és delami-

\footnotetext{
* Tel.: +36 88624000 / 6041; e-mail: boda@almos.uni-pannon.hu

** https://mscms.uni-pannon.hu/
} 
náció, vagyis a kaolinit szemcséinek kisebb lapkötegekre esése, esetleg exfoliáció, vagyis a szemcsékről egyedi lapok leválása megy végbe. Az interkalációval kezelt kaolinitnek vagy az egyedi lapokból kialakuló görbült/tekercses szerkezeteknek számos felhasználási lehetősége van.

A kaolinittel végzett kutatásaink homlokterében az interkaláció és a delamináció atomi szintủ modellezése, illetve a kialakult kaolinit-interkalátum komplexek szerkezetének vizsgálata állt. Munkánkban szorosan együttmúködtünk a kaolinit interkalációját kémiai laboratóriumi kísérletekben vizsgáló kutatókkal. A CHARMM ${ }^{19}$, az INTERFACE FF ${ }^{20}$ és $\mathrm{ClayFF}^{21}$ modellrendszerek alkalmazásával végeztünk atomi felbontású szimulációkat a Gromacs ${ }^{22}$ programcsomaggal. A kutatóhelyen rendelkezésre álló számítási kapacitás mellett - a nagyobb számításigényủ feladatokra - a németországi $\mathrm{PC}^{2} \mathrm{OCuLUS}$ szuperszámítógépet (Paderborn Center for Parallel Computing) használtuk.

A kaolinit-vendégmolekula rendszerek egyik fö jellemzője a kaolinitszemcsében levő lapok távolsága. A stabil, kísérletileg is kimutatható bázislaptávolságot az interkalált molekulák mennyiségének a kapott bázislaptávolságok függvényében való ábrázolásából lehet megállapítani. Szabadenergia-számításaink alapján azonban belátható volt, hogy ez a bázislaptávolság egy viszonylag széles tarto- mányt reprezentál. Vizsgáltuk a kaolinitlapok közé közvetlenül bevihető (elsődleges) interkalálószerekkel (karbamid, formamid, az n-metil-formamid, kálium- és ammónium-acetát) kialakuló komplexeket, illetve további komplexeket, közvetlenül be nem vihető interkalálószerekkel (metanol, hexil-amin, cetil-trimetil-ammónium-klorid).

A kálium-acetát és az ammónium-acetát a kaolinit elsődleges interkalálószerei, és a velük létrejövő szerkezetek az egyik legnagyobb rétegtávolsággal jellemzett, egylépéses direkt interkalációval létrejövő komplexek. Így ezek az exfoliációs kísérletek fontos potenciális előanyagai. Interkalációs szimulációs vizsgálatokból megállapítottuk a vendégmolekulák lehetséges mennyiségét, elrendeződését és a molekulák legjellemzőbb beállásait a kaolinitlapok közötti térben. Nagyszámú, felderítő jellegủ szimulációval megbecsültük a kísérletekben megfigyelt, szokásosnál nagyobb bázislaptávolságú komplexek (pl. a kálium-acetáttal az 1,4 nm-es komplex) víztartalmát, és segítséget tudtunk nyújtani valószínủ szerkezetük leírásában. A vendégmolekulák a kaolinitlapok között általában kétrétegü elrendezést mutattak (1. ábra), de az ammónium-acetát esetében sikerült a vízmolekulák háromrétegü elrendeződését kimutatni egy, a kísérletekben öregítés után detektált 1,7 nm-es komplexre. ${ }^{23-25}$

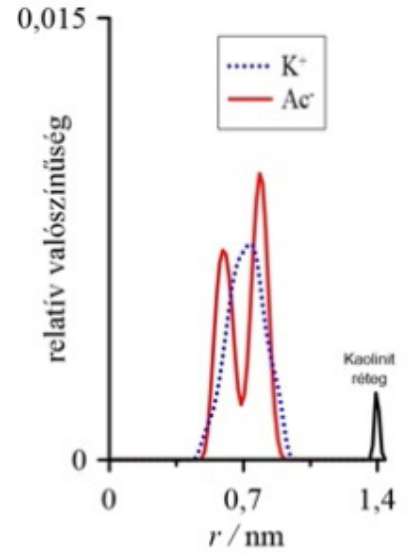

a

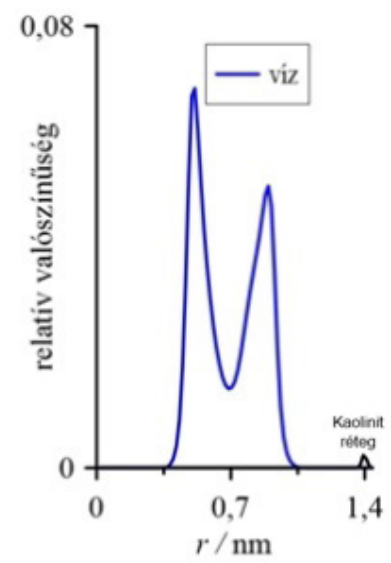

b

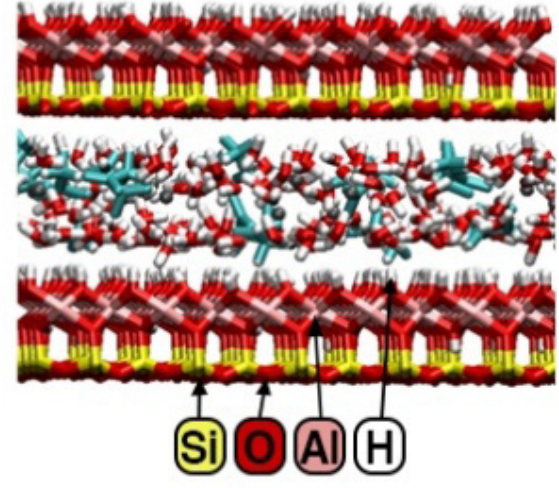

c

1. ábra. Sürüségeloszlás görbék (a,b) és szimulációs pillanatkép (c) a 69,6 m/m\% kaolinit, 11,0 m/m\% kálium-acetát és $19,4 \mathrm{~m} / \mathrm{m} \%$ víz összetételü 1,41 nm rétegtávolsággal jellemzett komplex esetén.

Az egymással rokon formamid, karbamid, és n-metil-formamid, mint primer interkalálószerek interkalációjának összehasonlítását is elvégeztük. A kísérleti eredményekkel egybehangzóan a kaolinit-amid komplexek 1,0 és 1,1 nm között egymáshoz hasonló bázislaptávolsággal rendelkeznek, az interkalált molekulák méretkülönbségéből adódó kis eltérésekkel. Minden anyagra továbbá egy második stabil bázislaptávolság-érték is megállapítható volt 1,4-1,5 nm környékén. A szokásos vizsgálatokon kívül a komplexekre kölcsönhatási energiákat is számítottunk, és ennek segítségével feltártuk a molekuláknak a kaolinit oktaéderes és tetraéderes rétegével vett kölcsönhatásai közötti különbsé- geket. Az irodalmi forrásokat megerösítve megállapítottuk a kaolinit oktaéderes rétegének kitüntetett szerepét. A kölcsönhatási energiák hőmérsékletfüggéséből magyarázatot adtunk arra a többlépéses interkalációval végrehajtott exfoliációs kísérleti tapasztalatra, hogy míg szobahőmérsékleten az interkalált karbamid metanolos mosással nehezen távolítható el, addig $100 \square$ C-on a metanolcsere-kísérletekben a legjobban használható ${ }^{26}$ (2. ábra).

A kaolinit-metanol komplex létrehozása egy fontos köztes állomása a kaolinit exfoliálásának. A laboratóriumi kísérletekben kapott eredmények alátámasztására illetve 
magyarázatára molekuláris szimulációs vizsgálatokat végeztünk, esetenként vízmolekulák hozzáadásával. Mivel a metanol képes kémiai reakcióba lépni az agyagásvány belső felületi $\mathrm{OH}$-csoportjaival, ezért a felületi $\mathrm{OH}$-csoportok metoxi-csoportokkal való, különbözö arányú helyettesítésének hatását is megvizsgáltuk. Megállapítottuk, hogy a felület módosításának mértéke csak kissé befolyásolja a kapott rétegtávolságokat, hasonlóan a kismennyiségủ víz jelenlétéhez. Fontos észrevételként megállapítottuk, hogy a kísérleti eredményekben tapasztalt változatosság magyarázatára nem feltétlenül szükséges mobilis metanolt és/vagy vizet feltételezni a lapok között. ${ }^{27}$

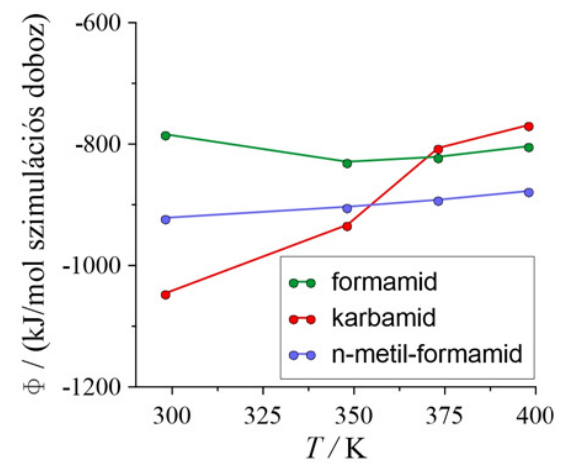

2. ábra. A vendégmolekulák és az őket tartalmazó rétegközi teret határoló (legközelebbi) kaolinitlapok közötti átlagos kölcsönhatási energiák változása a hőmérséklet függvényében.

A cetil-trimetil-ammónium-klorid, mint tercier interkalálószer interkalációjakor létrejövő és a kaolinitlap exfoliációját indukáló komplexről a kapcsolódó laborkísérleteket támogató szimulációkkal kimutattuk, hogy - ha metanolos köztes interkalációt alkalmaznak - nem elhanyagolható metanoltartalma lesz. A komplexben a láncszerủ molekulák eloszlása diffúz (nem alakul ki rétegeződés), és - szemben az eddigi felfogással - legvalószínűbb orientációjuk a kaolinitlapokkal közel párhuzamos lesz. ${ }^{28}$

Ma sok anyagtudománnyal foglalkozó szakember érdeklödésének fókuszában áll a kaolinit exfoliációjának kérdése. Ennek atomi léptékủ szimulációja több elvi és technikai problémát is felvet. Kaolinit exfoliációjával kapcsolatosan is végeztünk szimulációkat, olyan részletességü és méretü modellrendszerrel, amilyennel tudomásunk szerint agyagásványokat előtte még nem vizsgáltak. A kialakított élethü méretủ, 8 darab $103 \mathrm{~nm} \times 103 \mathrm{~nm}$-es lapból összeálló kaolinitszemcsének az interkalálószerrel együtt létrehozott molekuláris szimulációs modellrendszerében egy tercier interkalálószer, hexil-amin alkotta az oldatfázist. A 100 milliót jóval meghaladó atomi kölcsönhatási centrumot tartalmazó rendszer több hónapos szimulációjához szuperszámítógépet használtunk. Az így is csak néhány ns-ot felölelő szimulált folyamatban az egyik szélső kaolinitlap a szimuláció befejezésekor még intenzív morfológiai változásban volt, mutatva a lapleválás első lépéseit (ld. 3. ábra). Bár a teljes exfoliációs folyamat, illetve az esetleges nanocső-kialakulás a számítás limitált időtartományán kívül esett, ez a szimuláció mégis atomi szinten tudott betekintést nyújtani a nanocsövek/nanotekercsek kialakulásának kezdeti szakaszába. ${ }^{29}$

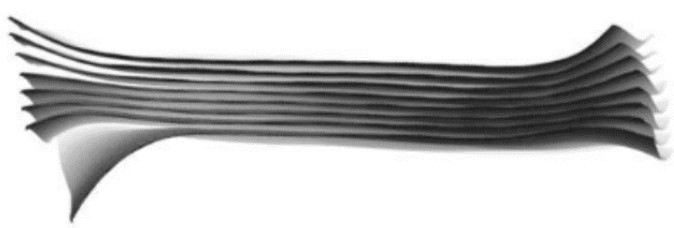

3. ábra. Egy szimulációs pillanatkép a valós méretű kaolinitlapok szimulációiból hexil-amin oldószerrel.

A kísérleti eredmények azt mutatják, hogy a kaolinitszemcsékről lehasadó, szabaddá váló lapok sík geometriája megváltozik, feltekerednek, görbült, adott esetben nanocsöves/ nanotekercses szerkezetet vesznek fel. Elméleti megfontolások szerint a kaolinit tetraéderes és oktaéderes rétegének eltérő hossza miatt a szerkezetben belső feszültség van, és - ha nincsenek hidrogénkötésekkel szorosan kapcsolódó szomszédos lapok, amelyek kifeszítik a lap síkját - ez a lap deformációjához vezet. Az elfogadott nézet szerint a kaolinitlapok úgy tekerednek fel, hogy az oktaéderes réteg kerül a belső oldalra.

Az ilyen típusú folyamatok jobb megértéséhez közel 1 millió atomból álló, valós méretü kaolinitlappal is végeztünk atomi felbontású szimulációkat. A szokásos szimulációkban használt periodikus, ezáltal kvázi-végtelen hosszúságú lapok nem tudják ezt a viselkedést visszaadni, és az ilyen, de nemperiodikus, szabadon álló lapok a tapasztalatok alapján irreális görbületeket mutatnak (az utóbbi kézenfekvő módon a külső felületi és belső atomok valóságostól jelentősen eltérő arányából következik). Eredményeink érzékenyeknek bizonyultak az alkalmazott potenciálmodellre, a kölcsönhatások levágási hosszára, illetve a hosszú távú korrekciókra. Megállapítottuk pl., hogy az INTERFACE modellrendszer használatakor az Si-O kötés egyensúlyi kötéstávolságának csupán 1,5\%-nyi növelése elegendő ahhoz, hogy a feltekeredés iránya megforduljon. A szimulációkból kapott szerkezetek (egyenletesen meghajolt lapok, nanocsövek, kettős feltekeredésű csöves szerkezetek) hasonlóak voltak a nagyfelbontású elektronmikroszkópos vizsgálatokban megfigyeltekhez (ld. 4.ábra). Szimulációinkban az elméleti várakozással szemben mindkét feltekeredési irányt detektáltuk, ami ma már, a legújabb elektronmikroszkópos megfigyelések fényében nem kizárható lehetőség. ${ }^{30}$

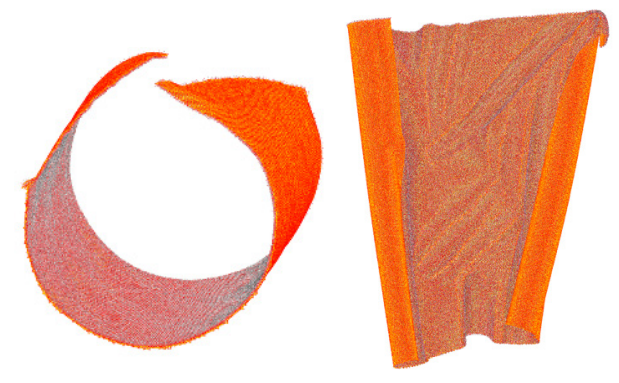

4. ábra. Két eltérő szerkezetet mutató szimulációs pillanatkép a valós méretű, szabadon álló kaolinitlapok atomi felbontású szimulációiból. 


\section{Skálázási jelenségek nanopórus alapú eszközökben}

A kutatócsoport munkája során különböző felbontású modelleket használ. Míg a kaolinitra vonatkozóan atomi felbontású modelleket (2. fejezet), addig a nanopórusokra vonatkozó vizsgálatainkban legtöbbször redukált modelleket használtunk. A redukált modellek lényege, hogy a rendszert alkotó részecskék (atomok, molekulák, ionok) egy részét, azaz a szabadsági fokok egy részét nem explicit, hanem implicit módon vesszük figyelembe.

Az elektrolitoldat esetében például a vízmolekulákat egy kontinuum háttérrel lehet helyettesíteni. Az ezzel való kölcsönhatást energetikai szempontból az ionok között ható Coulomb kölcsönhatást árnyékoló dielektromos háttér, $\varepsilon=78,45$, dinamikai szempontból az ionok diffúziós együtthatójával, $D_{i}(\mathbf{r})$, vesszük figyelembe. A membránt és a pórus falát lehet merev falakkal modellezni, a falon lévő töltött csoportokat pedig ponttöltésekkel vagy egy folytonos felületi töltéssűrűséggel.

A redukált modellek előnye részben az, hogy kisebb számítási kapacitás is elegendő a tanulmányozásukhoz, részben pedig az, hogy ezekkel a modellekkel a rendszer lényeges összetevőire tudunk koncentrálni.? Több olyan publikációnk jelent meg, amelyekben egy multiskálás modellezési keretben a nanopórust több modellezési szinten (atomi felbontás, redukált modell, illetve kontinuum modell) vizsgáltuk, és az eredményekből arra vontunk le következtetéseket, hogy a redukált modellekben kiátlagolt szabadsági fokok valóban a kevésbé lényeges szabadsági fokok közé tartoznak-e. ${ }^{31-33}$

Ebben a tanulmányban azokból az eredményeinkből adunk ízelítőt, amelyeket egy redukált modell keretein belül kaptunk a Nernst-Planck (NP) egyenlethez csatolt Lokális Egyensúlyi Monte Carlo (LEMC) módszerrel ${ }^{34}$.

Ez egy hibrid eljárás, ahol az áramsürüséget, $\mathbf{j}_{i}(\mathbf{r})$, a NP transzportegyenletből számoljuk:

$$
\mathbf{j}_{i}(\mathbf{r})=-\frac{1}{k T} D_{i}(\mathbf{r}) c_{i}(\mathbf{r}) \nabla \mu_{i}(\mathbf{r}),
$$

ahol a $c_{\mathrm{i}}(\mathbf{r})$ koncentrációprofil és a $\mu_{i}(\mathbf{r})$ kémiai potenciálprofil között egy összefüggésre van szükség, amit az LEMC szimulációs módszer szolgáltat. A módszer egy nagykanonikus alapú MC eljárás, ahol nincs globális egyensúly, ellenben a rendszer kis térfogatelemeiben lokális egyensúlyt feltételezünk, amit a $\mu_{i}(\mathbf{r})$ értékkel jellemzünk. Ennek a gradiense az ionáram hajtóereje. Az NP egyenletben található a diffúziós együttható, $D_{i}(\mathbf{r})$, míg a dielektromos állandó, $\varepsilon$, a töltött merevgömbökként modellezett ionok közötti kölcsönhatásban jelenik meg az LEMC szimulációkban.

A nanopórusok az ionok szabályozott transzportját bonyolítják le két tömbfázisú elektrolitoldat között egy membránon keresztül. A nevüket onnan kapták, hogy sugaruk, $R$, a nanométer tartományba esik, de a tulajdonságaik szempontjából az a legfontosabb, hogy ez a sugár összemérhető az elektrolit Debye-féle árnyékolási hosszával:

$$
\lambda_{\mathrm{D}}=\left(\frac{c e^{2}}{\varepsilon_{0} \varepsilon k T} \sum_{i} z_{i}^{2} v_{i}\right)^{-1 / 2},
$$

azaz $R \sim \lambda_{\mathrm{D}}$. Ebben az egyenletben $c$ a sókoncentráció, $v_{i}$ az $i$-ik ion sztöchiometriai együtthatója, $z_{i}$ a töltésszáma, $e$ az elemi töltés, $\varepsilon_{0}$ a vákuum permittivitása, $k$ a Boltzmann állandó, és $T$ az abszolút hőmérséklet (298,15 K).

Amennyiben $R>>\lambda_{\mathrm{D}}$, mikropórusokról beszélünk; a pórus közepén kialakul egy tömbfázis. Amennyiben $R<<\lambda_{\mathrm{D}}$, a pórus töltött falánál kialakuló elektrolitikus kettősrétegek dominálják a pórust, a pórus közepén ezek a kettősrétegek átlapolódnak, és leginkább az ellenion lesz jelen a pórusban egy töltött fal mellett.

Ez utóbbi esetben a pórus falán kialakított töltésmintázatok teszik lehetővé, hogy a pórus különböző érdekes vezetési tulajdonságokat mutasson. Egy egyenletesen negatívan töltött $(-\sigma)$ pórus ${ }^{15}$ például szelektív lesz az ellenionra, azaz a kationra (5. ábra első oszlopa) ${ }^{* * *}$. Ekkor azt mondjuk, hogy az eszköz válaszfüggvénye a szelektivitás, amit a kationáram teljes áramból vett részarányaként definiálhatunk:

$$
S_{+}=\frac{I_{+}}{I_{+}+I_{-}} .
$$

Ez az érték 1, ha a pórus tökéletesen szelektív, és 0,5 , ha egyáltalán nem szelektív.

Amennyiben egy bipoláris nanopórusról van szón ${ }^{13,14,16}$, azaz a pórus egyik felében pozitív, $\sigma_{\mathrm{p}}=\sigma$, a másikban negatív, $\sigma_{\mathrm{n}}=-\sigma$, töltés van a pórus falán (5. ábra második oszlopa), akkor az egyik régióban a kationra, míg a másik régióban az anionra nézve alakul ki kiüresedési zóna (olyan térrész, ahol kicsi az adott komponens koncentrációja).

Ez behatárolja a teljes áramot. Az eszköz válaszfüggvénye az egyenirányítás, mivel a kiüresedési zónák mélysége függ az alkalmazott feszültség előjelétől. A külső feszültség módosítja a koncentrációprofilokat, mert megváltoztatja az ionok potenciális energiáját. A feszültség egyik elöjelénél csökkenti, az ellenkező előjelénél növeli. Gondoljunk arra, hogy a bipoláris nanopórus töltéseloszlása dipólus-szerü; a külső térrel való kölcsönhatás tehát függ a külső tér irányától, azaz a feszültség előjelétől.

Az egyenirányítást (,,ionic current rectification”) a következőképpen definiálhatjuk:

$$
\mathrm{ICR}=\frac{I^{\mathrm{ON}}-I^{\mathrm{OFF}}}{I^{\mathrm{ON}}+I^{\mathrm{OFF}}},
$$

\footnotetext{
*** A $\sigma$ paraméter felületi töltéssürüséget jelöl, mindig pozitív, és egyetlen paraméterként jellemzi a teljes töltésmintázatot mindhárom eszköznél.
} 
ahol $I^{\mathrm{ON}}$ és $I^{\mathrm{OFF}}$ a teljes áramok a feszültség nyitott, $U$, illetve zárt, $-U$, állású előjelénél. Ez az érték 1, ha a pórus tökéletesen egyenirányít, és 0 az ellenkező esetben, amikor az áram vs. feszültség görbe tökéletesen szimmetrikus.

A harmadik fajta nanopórus három régióra osztható ${ }^{12}$. A két szélső régió töltése rögzített; ez a régió határozza meg a nanopórus fö töltéshordozó ionját. Példánkban $\sigma_{\mathrm{n}}<-\sigma$, azaz a fö töltéshordozó a kation. A középső régió töltéssürüsége, $\sigma_{\mathrm{X}}$, változtatható; ez határozza meg a pórus nyitott vagy zárt állását. Ez egyfajta tranzisztor-viselkedés, ezért erre az eszközre ezentúl tranzisztorként hivatkozunk. Ha $\sigma_{\mathrm{x}}<0$, akkor a póruson keresztül zavartalanul folyhat a kationok árama; ha azonban $\sigma_{\mathrm{x}}>0$, akkor ebben a régióban a kationokra nézve kiüresedési zóna képződik és az eszköz zárt állásba kerül. A válaszfüggvény a kapcsolási függvény,

$$
\mathrm{Sw}=\frac{I^{\mathrm{ON}}-I^{\mathrm{OFF}}}{I^{\mathrm{ON}}+I^{\mathrm{OFF}}},
$$

ami az egyenirányítással rokonítható, amennyiben definiálunk a pórusra egy nyitott és egy zárt állást illetve a hozzájuk tartozó áramerősségeket, $I^{\mathrm{ON}}$ és $I^{\mathrm{OFF}}$, amik most két különböző $\sigma_{\mathrm{X}}$ értékhez tartoznak: $\sigma_{\mathrm{X}}^{\mathrm{ON}}=-\sigma$ és $\sigma_{\mathrm{X}}^{\mathrm{OFF}}=\sigma$ (a feszültség előjele nem releváns, mivel a pórus szimmetrikus).

A skálázhatóság alatt azt értjük, hogy a nanopórust jellemző paraméterekből össze tudunk állítani egy olyan kompozit paramétert, amitől a válaszfüggvény egyértelmüen függ. Ezt a paramétert skálázási paraméternek hívjuk. A nanopórusra illetve a mérési elrendezésre jellemző, könnyen változtatható paraméterek a következök: a pórus sugara, $R$, hossza, $H$, a töltésmintázatot minden esetben jellemző $\sigma$ paraméter, az elektrolit koncentrációja, $c$, amiről feltesszük, hogy a membrán két oldalán ugyanaz, és a feszültség, $U$. Az ionok jellemzői további paraméterek lehetnek, de itt felteszszük, hogy 1:1 rendszerről van szó, azaz $z_{+}=1$ és $z_{-}=-1$, és hogy minden ion átméröje egységesen $0,3 \mathrm{~nm}$ és diffúziós állandója $1,334 \times 10^{-9} \mathrm{~m}^{2} / \mathrm{s}$.

A háromféle rendszerre az eredményeket a töltésmintázat bonyolultsági fokának sorrendjében mutatjuk be (szelektív $\rightarrow$ egyenirányító $\rightarrow$ tranzisztor), de meg kell jegyeznünk, hogy a skálázhatóságot először a tranzisztor esetében ismertük fel ${ }^{12}$, aztán a bipoláris nanopórusra vizsgáltuk meg $^{13}$, és a végére hagytuk az elvileg legegyszerübb esetet, az egyenletesen töltött szelektív nanopórust ${ }^{15}$.

A tranzisztorra vonatkozó eredményeinkböl világos volt ${ }^{12}$, hogy az $\lambda_{\mathrm{D}} / R$ arány egy fontos paraméter, mivel a kettősrétegek átlapolódásának mértékét jellemzi. Nem tartalmazza azonban sem a felületi töltéssürüséget, $\sigma$, sem a pórus hosszát, $H$, sem a feszültséget, $U$.

A szelektív nanopórus esetén létezik az irodalomban egy kompozit paraméter, a Dukhin szám ${ }^{35-37}$, amit hagyományosan a következőképpen fejeznek ki:

$$
\mathrm{Du} \equiv \frac{\sigma}{e R c}
$$

ami megfelelő mértékegységek használata esetén egy egység dimenziójú mennyiség. Az itt tanulmányozott 1:1es elektrolitra $\lambda_{\mathrm{D}}^{2}=1 /\left(8 \pi l_{\mathrm{B}} c\right)=1 /\left(l_{\mathrm{B}}^{*} c\right)_{\text {a Debye hossz, }}$ $l_{\mathrm{B}}=e^{2} / 4 \pi \varepsilon_{0} \varepsilon k T$ a Bjerrum hossz, és $l_{\mathrm{B}}^{*}=8 \pi l_{\mathrm{B}}$. Ekkor a Dukhin szám felírható a következő formában is:

$$
\mathrm{Du}=\frac{\sigma l_{\mathrm{B}}^{*} \lambda_{\mathrm{D}}^{2}}{e R} .
$$

2021-es publikációnkban ${ }^{15}$ megmutattuk, hogy a Dukhin szám valóban jól használható skálázási paraméterként, amennyiben a pórus végtelen hosszú, $H \rightarrow \infty$, azaz elektromosan tökéletesen semleges (lásd a Sarkadi és mtsai. (2021) ${ }^{15}$ cikk 4. ábráját). Ha azonban a pórus véges hoszszúságú, akkor Du már nem megfelelő skálázási paraméter (lásd a Sarkadi és mtsai. (2021) ${ }^{15}$ cikk 6. ábráját). Megmutattuk, hogy véges hosszúságú pórus esetén az ún. módosított Dukhin szám müködik jól:

$$
\mathrm{mDu} \sim \mathrm{Du} \frac{H}{\lambda_{\mathrm{D}}}=\frac{\sigma l_{\mathrm{B}}^{*} \lambda_{\mathrm{D}} H}{e R},
$$

ami már tartalmazza a pórus hosszát, $H$, is. Ezt az 5. ábra első oszlopában a középső sorban mutatott ábra szemlélteti, ami a szelektivitást, $S_{+}$, mutatja az $\mathrm{mDu}$ függvényében. $H=6$ nm-re (más $H$ értékekért lásd a Sarkadi és mtsai. (2021) ${ }^{15}$ cikk 8. ábráját). A különböző görbék különböző koncentrációkra és így különböző árnyékolási hosszakra vonatkoznak. Az egy adott görbéhez tartozó pontok különböző $\sigma$ értékeknél kapott eredményeket jelölik. A különböző paraméterekhez tartozó pontok a vezérgörbéhez (egy szigmoid) igazodnak, azaz a skálázás múködik. A feszültség, amennyiben nem túl nagy, nem annyira fontos paraméter az egyenletesen töltött pórus esetében (a feszültségfüggésért lásd a Sarkadi és mtsai. (2021) ${ }^{15}$ cikk 9. ábráját).

Az alsó sorban a koncentrációprofilok azt szemléltetik, hogy nagyobb $\sigma$ értéknél a kation- és anion profilok jobban szétválnak, mivel a nagyobb töltéssürüség jobban vonzza a kationokat és jobban taszítja az anionokat.

A bipoláris nanopórus esetében korábbi publikációinkban megmutattuk, hogy a skálázás érvényes, amennyiben az $\lambda_{\mathrm{D}} / R$ paramétert használjuk 1:1 elektrolitokra rögzített $\sigma$, $H$, és $U$ esetén ${ }^{13}$. Azt is megmutattuk, hogy multivalens ionokat tartalmazó elektrolitokra $(2: 1,3: 1,2: 2)$ is érvényes a skálázás, ha $\sigma$ nem túl nagy és a $R /\left(\lambda_{\mathrm{D}} \sqrt{z_{+}\left|z_{-}\right|}\right)$skálázási paramétert használjuk. Később megmutattuk, hogy a skálázhatóság sérül multivalens elektrolitok és nagy $\sigma$ esetén a fellépő erős elektrosztatikus korrelációk és az annak eredményeképpen megjelenő töltésinverzió és túltöltés miatt ${ }^{14}$. 

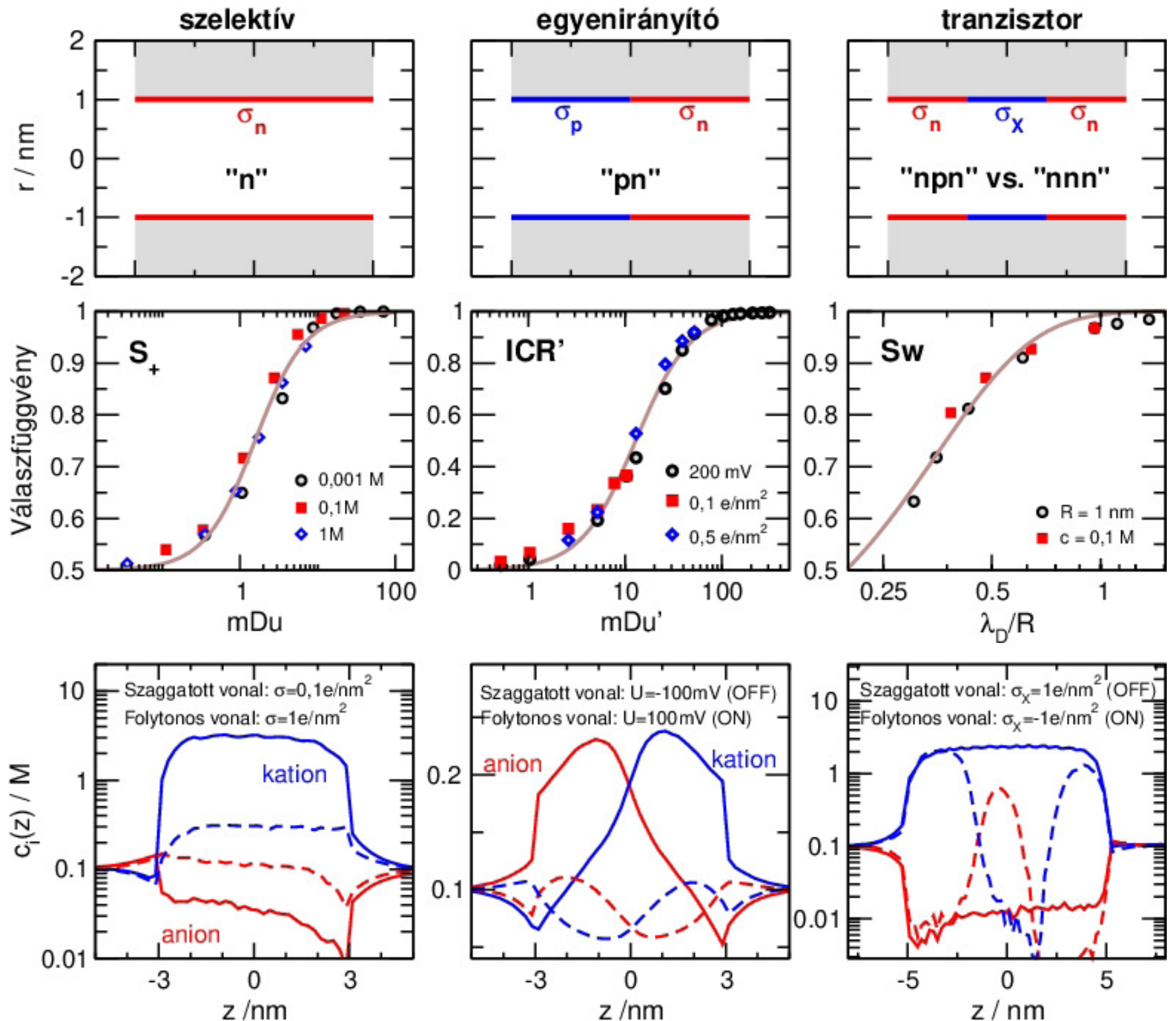

5. ábra A háromféle töltésmintázathoz tartozó nanoeszközre vonatkozó eredmények balról jobbra láthatók. Bal oldali oszlop: szelektív pórus egyenletesen töltött $\left(\sigma_{\mathrm{n}}\right)$ fallal (,n'); középső oszlop: egyenirányító bipoláris pórus $\sigma_{\mathrm{p}}=\sigma$ és $\sigma_{\mathrm{n}}=-\sigma$ töltéssürüségü tartományokkal (〈pn)); tranzisztorként viselkedő pórus, ahol az áram a középső tartomány töltéssűrủségével $\left(\sigma_{\mathrm{x}}\right)$ hangolható; a nyitott $(\mathrm{ON})$ és a zárt $(\mathrm{OFF})$ állásokat a $\sigma_{\mathrm{x}}^{\mathrm{ON}}=-\sigma$ és $\sigma_{\mathrm{X}}^{\text {OFF }}=\sigma$ töltéssủrüségekkel definiáljuk. Felső sor: a töltésmintázat vázlata. Középső sor: a skálázási görbék (válaszfüggvény vs. skálázási paraméter; ezek definíciója a föszövegben található) a három esetre. Szelektív pórus: $S_{+}$vs. mDu, paraméterek: $H=6 \mathrm{~nm}, R=1 \mathrm{~nm}, U=200 \mathrm{mV}$, a különböző koncentrációkhoz tartozó görbék $\sigma$ változtatásával készültek. Egyenirányító pórus: ICR' vs .mDu', paraméterek: $H=6 \mathrm{~nm}, R=1 \mathrm{~nm}, c=0,1 \mathrm{M}$, a $U=200 \mathrm{mV}$-ra vonatkozó pontoknál $\sigma$ változik, míg a $c=0,1$ és $0,5 \mathrm{e} / \mathrm{nm}^{2}$-re vonatkozó pontoknál $U$ változik. Tranzisztor: Sw vs. $\lambda_{\mathrm{D}} / R$, paraméterek: $H=10 \mathrm{~nm}, U=200 \mathrm{mV}, \sigma_{\mathrm{n}}=-\sigma, \sigma_{\mathrm{x}}= \pm \sigma\left(\sigma=1 \mathrm{e} / \mathrm{nm}^{2}\right)$, az $R=1 \mathrm{~nm}$ pontoknál $c$ változik, míg a $c=0,1 \mathrm{M}$ pontoknál $R$ változik. A barna vonalak az összes pontra illesztett szigmoid görbék. Alsó sor: koncentrációprofilok. Szelektív pórus: kation (kék) és anion (piros) profilok két különböző $\sigma$ értékre és $c=0,1 \mathrm{M}$-ra. Egyenirányító pórus: kation (kék) és anion (piros) profilok $U=100 \mathrm{mV}(\mathrm{ON})$ és $U=-100 \mathrm{mV}(\mathrm{OFF})$ feszültségekre $\left.c=0,1 \mathrm{M}, \sigma=0,1 e / \mathrm{nm}^{2}\right)$. Tranzisztor: kation (kék) és anion (piros) profilok $\sigma_{\mathrm{x}}=-1 \quad e / \mathrm{nm}^{2}(\mathrm{ON})$ és $\sigma_{\mathrm{x}}=1 \quad e / \mathrm{nm}^{2}$ (OFF) felületi töltéssürüségekre a középső tartományban

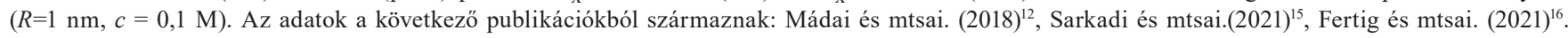


A Sarkadi és mtsai. (2021) $)^{15}$ publikációban bevezetett mDu paraméter arra inspirált bennünket, hogy megnézzük, hogy vajon az mDu szám nem lenne-e jó skálázási paraméter bipoláris nanopórusokra ${ }^{16}$. Az eredmények egyértelmüen jelezték, hogy ez a helyzet, sőt az $\mathrm{mDu} U / U_{0}$-val való szorzásával még a feszültséget is sikerült bevenni a paraméterek közé:

$$
\mathrm{mDu}^{\prime}=\mathrm{mDu} \frac{U}{U_{0}}=\frac{\sigma l_{\mathrm{B}}^{*} \lambda_{\mathrm{D}} H}{e R} \frac{U}{U_{0}},
$$

ahol $U_{0}$ egy alkalmasan választott feszültségérték $\left(U_{0}=200\right.$ $\mathrm{mV}$, ebben a munkában); fö szerepe az, hogy mDu' egység dimenziójú maradjon. Az erős feszültségfüggés oka az, hogy a nagyobb feszültség jobban módosítja a koncentrációprofilokat, jobban szétválasztja őket a nyitott és a zárt állásban, ezért nagyobb egyenirányítást eredményez. A szelektív pórusnál ezzel szemben a feszültség fö dolga az, hogy az ionáramnak hajtóerőt biztosítson; a szelektivitást elsősorban a felületi töltés eredményezi.

A középső oszlopban a skálázási görbe (ICR' vs. mDu') hasonló szigmoid alakú görbét eredményez, mint a szelektív esetben és a különböző paraméterekhez tartozó pontok erre a görbére esnek. A koncentrációprofilok azt szemléltetik, hogy a feszültség előjelének megváltoztatása milyen hatással van a kétféle ion kiüresedési zónáira: az OFF állásban a kiüresedési zónák mélyebbek.

A tranzisztor esetében viszonylag kevés adattal rendelkezünk és csak a sugártól, $R$, és a koncentrációtól, $c$, való függést vizsgáltuk meg. A skálázási paraméter, $\lambda_{\mathrm{D}} / R$, része a Dukhin-számnak; míg a további paraméterektől való függés még vizsgálatra vár. A kapcsolási függvényre a $\lambda_{\mathrm{D}} / R$ függvényében mindenesetre müködik a skálázás.

A koncentrációprofilok azt mutatják, hogy a $\sigma_{\mathrm{x}}$ paraméter különböző értékeinél hogy alakul a kation (a töltéshordozó komponens) koncentrációja a középső zónában: a $\sigma_{\mathrm{X}}^{\mathrm{ON}}=-\sigma$ értéknél a kation koncentrációja nagy az egész pórusban, tehát a kation vezeti az áramot, míg a $\sigma_{\mathrm{X}}^{\mathrm{OFF}}=\sigma$ értéknél a kationnak a középső tartományban kiüresedési zónája alakul ki, ekkor tehát nem vezet.

A skálázhatóság jelensége azért hasznos, mert lehetővé teszi a nanopórus, mint eszköz viselkedésének predikcióját. Ha ugyanis kísérleti eredményekkel rendelkezünk a paraméterek egy adott kombinációjára, azaz a skálázási paraméter egy adott értékére, akkor következtetéseket vonhatunk le arra vonatkozóan, hogy a paraméterek más kombinációinál milyen lesz az eszköz müködése.

\section{4. Összefoglalás}

Az ebben a munkában ismertetett kétféle anyagi rendszerre vonatkozó eredményeink azt mutatják, hogy a modellezés és a számítógépes szimuláció hasznos vizsgálati eszköz a komplex molekuláris rendszerek tanulmányozásában. Komplex molekuláris rendszer alatt itt most olyan újsze- rü anyagokat illetve nanotechnológiai eszközöket értünk, amiknek a működése nem triviálisan függ a mérhető makroszkopikus tulajdonságaiktól, azaz e rendszerek mikroszkopikus szintű tanulmányozására és megértésére van szükség.

\section{Köszönetnyilvánítás}

Köszönetet mondunk a Nemzeti Kutatási, Fejlesztési és Innovációs Hivatal (NKFIH) támogatásáért, projekt K124353. Hálásak vagyunk szerzőtársainknak az izgalmas közös munkáért: Jadran Vrabec, Dirk Gillespie, Rutkai Gábor, Kristófné Makó Éva, Bartłomiej Matejczyk.

\section{Hivatkozások}

1. Hille, B.: Ion Channels of Excitable Membranes, 3rd ed., Sinauer Associates: Sunderland, 2001

2. Boda, D.; Nonner, W.; Valiskó, M.; Henderson, D.; Eisenberg, B.; Gillespie, D. Biophys. J. 2007, 93(6), 1960-1980. https://doi.org/10.1529/biophysj.107.105478

3. Boda, D.; Valiskó, M.; Henderson, D.; Eisenberg, B.; Gillespie, D.; Nonner, W. J. Gen. Physiol. 2009, 133(5), 497-509. https://doi.org/10.1085/jgp.200910211

4. Malasics, M.; Boda, D.; Valiskó, M.; Henderson, D.; Gillespie, D. Biochim. et Biophys. Acta-Biomembranes 2010, 1798(11), 2013-2021. https://doi.org/10.1016/j.bbamem.2010.08.001

5. Boda, D. In Ann. Rep. Comp. Chem., Wheeler, R. A. Ed.; Elsevier, 2014.; Vol. 10, pp 127-163. https://doi.org/10.1016/B978-0-444-63378-1.00005-7

6. Ható, Z.; Boda, D.; Gillepie, D.; Vrabec, J.; Rutkai, G.; Kristóf, T. Condens. Matt. Phys., 2016 19(1), 13802. https://doi.org/10.5488/CMP.19.13802

7. Boda, D.; Valiskó, M.; Gillespie, D. Entropy, 2020 22(11), 1259. https://doi.org/10.3390/e22111259

8. Mádai, E.; Valiskó, M.; Dallos, A.; Boda, D. J. Chem. Phys., $2017147(24), 244702$. https://doi.org/10.1063/1.5007654

9. Mádai, E.; Valiskó, M.; Boda, D. . J. Mol. Liq., 2019 283, 391-398. https://doi.org/10.1016/j.molliq.2019.03.078

10. Mádai, E.; Valiskó, M.; Boda, D. Phys. Chem. Chem. Phys., $2019117(20), 2793-2801$. https://doi.org/10.1039/C9CP03821C

11. Hohl, B.; Mádai, E.; Boda, D.; Valiskó, M. J. Mol. Liq., 2020 310, 112946. https://doi.org/10.1016/j.molliq.2020.112946

12. Mádai, E.; Matejczyk, B.; Dallos, A.; Valiskó, M.; Boda. D. Phys. Chem. Chem. Phys. 2018 20(37), 24156-24167. https://doi.org/10.1039/C8CP03918F

13. Fertig, D.; Matejczyk, B.; Valiskó, M.; Gillespie, D.; Boda, D. J. Phys. Chem. C, 2019 123(47), 28985-28996. https://doi.org/10.1021/acs.jpcc.9b07574

14. Fertig, D.; Valiskó, M.; Boda, D. Phys. Chem. Chem.Phys., 2020 22(34), 19033-19045. https://doi.org/10.1039/D0CP03237A

15. Sarkadi, Zs.; Fertig, D.; Ható, Z.; Valiskó, M.; Boda, D. . J. Chem. Phys., 2021 154(15), 154704. https://doi.org/10.1063/5.0040593 
16. Fertig, D.; Sarkadi, Zs.; Valiskó, M.; Boda, D. . Mol. Sim., 2021 in press $1-14$ https://doi.org/10.1080/08927022.2021.1939330

17. Allen, M. P.; Tildesley, D. J. Computer Simulation of Liquids, Clarendon Press, New York, 1987

18. Frenkel, D.; Smit, B. Understanding Molecular Simulation, 2nd ed., Academic Press, San Diego, 2002 https://doi.org/10.1016/B978-012267351-1/50005-5

19. MacKerell Jr., A. D.; Banavali, N.; Foloppe, N. Biopolymers 2000, 56(4), 257-265. https://doi.org/10.1002/1097-0282(2000)56:4<257: AID-BIP10029>3.0.CO;2-W

20. Heinz, H.; Lin, T-J ; Mishra, R. K.; Emami. F. S. Langmuir 2013, 29(6), 1754-1765. https://doi.org/10.1021/la3038846

21. Cygan, R. T.; Liang, J-J; Kalinichev, A. G. J. Phys. Chem. B 2004, 108(4), 1255-1266. https://doi.org/10.1021/jp0363287

22. Abraham, M. J.; Murtola, T.; Schulz, R.; Páll, Sz.; Smith, J. C.; Hess, B.; Lindahl, E. SoftwareX, 2015 1-2, 19-25. https://doi.org/10.1016/j.softx.2015.06.001

23. Makó, É; Rutkai, G.; Kristóf. T. J. Coll. Interface Sci., 2010 349(1), 442-445. https://doi.org/10.1016/j.jcis.2010.05.021

24. Makó, É; Kovács, A.; Ható, Z.; Zsirka, B.; Kristóf, T. J. Coll. Interface Sci., 2014, 431, 125-131. https://doi.org/10.1016/j.jcis.2014.06.006

25. Ható, Z.; Makó, É.; Kristóf, T. J. Mol. Model., 2014, 20, 2140 . https://doi.org/10.1007/s00894-014-2140-9

26. Kristóf, T.; Sarkadi, Zs.; Ható, Z.; Rutkai, G.Comp. Mat. Sci. 2018, 143, 114-125. https://doi.org/10.1016/j.commatsci.2017.11.010
27. Makó, É.; Kovács, A; Ható, Z.; Kristóf, T.Appl. Surf. Sci. 2015, 357, 626-634. https://doi.org/10.1016/j.apsusc.2015.09.081

28. Makó, É.; Kovács, A.; Katona, R.; Kristóf, T. Coll. Surf. Phys. Eng. Asp., 2016, 508, 265-273. https://doi.org/10.1016/j.colsurfa.2016.08.035

29. Ható, Z.; Rutkai, G.; Vrabec, J.; Kristóf, T. J. Chem. Phys., 2014, 141, 091102. https://doi.org/10.1063/1.4894756

30. Ható, Z; Vrabec, J, Kristóf T. Comp. Mater. Sci., 2021, 186 , 110037. https://doi.org/10.1016/j.commatsci.2020.110037

31. Ható, Z.; Valiskó, M.; Kristóf, T.; Gillespie, D.; Boda, D.

32. Phys. Chem. Chem. Phys., 2017 19(27), 17816-17826. https://doi.org/10.1039/C7CP01819C

33. Matejczyk, B.; Valiskó, M.; Wolfram, M-T.; Pietschmann, J-F.; Boda, D. J. Chem. Phys. 2017 146, 124125. https://doi.org/10.1063/1.4978942

34. Valiskó, M.; Matejczyk, B.; Ható, Z.; Kristóf, T.; Mádai, E.; Fertig, D.; Gillespie, D.; Boda, D. J. Chem. Phys., 2019 150, 144703. https://doi.org/10.1063/1.5091789

35. Boda, D.; Gillespie, D. J. Chem. Theor. Comput., 2012 8, 824-829. https://doi.org/10.1021/ct2007988

36. Bazant, M. Z.; Thornton, K.; Ajdari, A. Phys. Rev. E, 2004 70(2), 021506. https://doi.org/10.1103/PhysRevE.70.021506

37. Chu, K. T.; Bazant, M. Z. Phys. Rev. E, 2006 74(1), 011501. https://doi.org/10.1103/PhysRevE.74.011501

38. Bocquet, L.; Charlaix, E. Chem. Soc. Rev., 2010 39(3), 10731095. https://doi.org/10.1039/B909366B

\section{Computer simulation of natural and artificial nanopores}

The goal of the Modeling and Simulation of Complex Molecular Systems research group at the Center for Natural Sciences of the University of Pannonia is studying novel materials and nanodevices at the molecular level for the better understanding the behavior of these systems. Because this behavior is strongly dependent on microscopic features of these systems, sufficient understanding is not possible without the modeling and simulation techniques mastered by the group. In this work, we present two main research areas of the group in order to introduce the readers to this field of modern chemistry.

We studied the intercalation phenomena of kaolinite clay, and occasional delamination from the kaolinite particles. One of the basic features of kaolinite-guest molecule systems is the distance between the layers in the kaolinite grain. Based on MD simulations, we proved that its stability range is relatively wide as a function of the number of intercalated molecules, and (in line with previous studies) is located where the basal spacing does not change substantially with increasing guest molecule content.

Potassium acetate and ammonium acetate are important primary intercalating agents of kaolinite. From our simulations the amount of intercalated molecules, the arrangement of these guest molecules and the most characteristic orientation(s) of the molecules in the interlayer space were determined. The possible composition of complexes with larger basal spacing than usual was determined (the composition is difficult to determine in the experiments). Furthermore, the intercalation properties of other primary intercalating agents, formamide, urea, and n-methylformamide were compared. Along with the usual properties, the interaction energies for these complexes were analyzed and the results revealed the differences between the interaction of molecules with the octahedral and tetrahedral sheets of kaolinite. The formation of the kaolinite-methanol complex, as an important intermediate step in the exfoliation of kaolinite, was also studied to help interpret the results obtained in the laboratory experiments (role of water, grafting). The simulation results suggest that it is not necessary to assume the presence of mobile intercalated methanol and/or water in the interlayer space in order to explain the variability observed in the experimental results. Our further investigations with the tertiary intercalating agent, cetyltrimethylammonium chloride predict methanol-containing structures between methoxy-functionalized kaolinite layers with diffuse guest molecular arrangements.

Molecular simulations of kaolinite exfoliation were carried out with a model system of such detail and size that clay minerals have not been studied before. In the simulation system, the lifesized kaolinite particle was surrounded by a sufficient amount of tertiary intercalating agent, hexylamine. Although the entire exfoliation process and a possible nanotube formation are beyond the accessible simulation time range, the simulation provided some insight (at the atomic level) into the initial steps of such nanotube formation. In a further study, the curling of a single-layer, free-standing kaolinite nanoparticle, which consists of nearly 1 million atoms was examined. The structures obtained from classical MD simulations are similar to the structures observed experimentally by TEM measurements, and both of the two possible 
curling directions occurred. The findings raise the possibility that structural changes of real-life, free-standing kaolinite nanolayers can be sensitive to small effects from the environment (intercalation reagent, exfoliation procedure).

Nanopores realize the transport of ions through a membrane in a controlled manner. The "nano" prefix means that the radius of the pore $(R)$ belongs to the nanometer scale, but it also implies that $R$ is in the range of the screening length of the electrolyte measured, for example, in terms of the Debye length $\left(\lambda_{\mathrm{D}}\right)$. If $\lambda_{\mathrm{D}}>R$, the counterions dominate the pore (the radial double layers overlap), which makes the fabrication of nanopores with different device functions possible. The device function depends on the surface charge pattern $(\sigma(z))$ on the wall of the nanopore. If $\sigma$ is constant and uniform, the pore is selective. If the surface charge pattern is bipolar, the pore rectifies. In the case of a transistor-like setup, the nanopore can be switched with the surface charge of one of the regions.

Whether the device function is selectivity, rectification, or switching, the system exhibits a scaling behavior by which we mean that the device function is a smooth unambiguous function of a scaling parameter. The scaling parameter is a composite parameter put together from the experimentally controllable parameters of the nanopore system: the radius of the pore, $R$, the length of the pore, $H$, the concentration of the electrolyte, $c$ (related to $\lambda_{\mathrm{D}}$ ), the surface charge density, $\sigma$, and voltage, $U$.
In the case of the selective nanopore, we show that the Dukhin number defined as $\mathrm{mDu}=\sigma / e R c \sim \sigma \lambda_{\mathrm{D}}^{2} / e R$ is an appropriate parameter in the nanotube limit $(H \rightarrow \infty)$. Charge neutrality is enforced in this case as opposed to the finite channel, where axial double layers screen the interior of the pore and alter selectivity. We show that in the nanohole limit $(H \rightarrow 0)$, the modified Dukhin number defined as $\mathrm{mDu}=\mathrm{Du}\left(H / \lambda_{\mathrm{D}}\right)$ is the suitable scaling parameter. Bipolar nanopores with an axial positive/negative charge pattern are necessarily finite. We showed that $\mathrm{mDu}$ is a suitable scaling parameter in this case too. $\mathrm{mDu}$ now contains the voltage as well, because rectification scales with $U$ if it is not too large. The switching function in the case of the transistor scales with $\lambda_{\mathrm{D}} / R$ if all the other parameters are fixed.

In general, scaling is a useful property for two reasons. First, it is useful for nanopore design because we can make estimation for the device function for some set of the parameters on the basis of measurements for other sets of parameters. Second, scaling works only in limiting cases. For example, it works if the electrostatic correlations are not too strong. If multivalent ions are present, for example, scaling shows deviation from its classic mean-field behavior. In the case of strong ionic correlations, peculiar phenomena such as charge inversion and overcharging may occur leading to more complex devices. 